\title{
THE QUALITY CONTROL AND QUALITY MANAGEMENT IMPACT ON PROCESS APPROACH DEVELOPMENT
}

\author{
Marina Jovanović, Snežana Urošević \\ Technical Faculty in Bor, University of Belgrade, Serbia \\ Vojske Jugoslavije 12, 19210 Bor, Serbia \\ phone: $+381631035084,+381641503053$ \\ e-mail: mjovanovicanja@gmail.com, surosevic@tfbor.bg.ac.rs
}

\begin{abstract}
This paper presents the influence of quality control and quality management on the development of process approach. One of the most important quality management principles is called process approach. Process approach is increasingly applied in business organizations, primarily because of the positive economic effects that it brings with it. One of the most significant advantages of process approach is the ability to manage quality in all business segments of the organization. In addition, the importance of process approach is reflected in emphasizing desires, needs and expectations of customers. Quality control systems and quality management can play a very important role in process approach development, primarily because of the fact that they represent extremely important elements of every process. The underlying hypothesis we want to demonstrate in our work is that quality control and quality management have a tremendous impact on the development of process approaches in organizations. Quality control and quality management, in modern business conditions, are of great importance for the realization of all business activities within the organization. The development and efficient application of the process approach are one of the most important prerequisites for long-term profitability of the organization's operations and their market success.
\end{abstract}

Keywords: quality control, quality management, process, process approach.

\section{INTRODUCTION}

Market globalization and the development of modern information and telecommunication technologies have led to an increase in customer interest in quality of products and services offered to them. This interest is particularly emphasized in economically richer and more developed markets where the customers are extremely conscious about quality. Almost all the authors dealing with quality issues point out that quality has become one of the most important factors affecting organizational success in all activities in modern business conditions.

Despite the fact that quality is viewed as something new and modern, by analyzing the development of human societies, we can conclude that it is already seen as one of the key features of products and services. Care about quality was always present, and its intensity differed depending on the level of social community development.

Changes in the markets that have taken place over the last few decades have significantly changed the relationship of all segments of society to quality. In addition to focusing on the quality of products and services, attention is also paid to the quality of processes that take place within organizations. With the development of ISO 9000 Series Quality Standards, an increasing emphasis is placed on quality control of all supporting processes in organizations, not just those processes that are directly related to product production or provision of services.

Quality control systems and quality management can play a very important role in process approach development, primarily because of the fact that they represent extremely important elements that take place in organizations. The underlying hypothesis we want to

IRTIIE Vol. 6, No. 2, 2018 ISSN 1314-8788 (print), ISSN 1314-8796 (online), doi: 10.15547/artte.2018.02.015 
demonstrate in our work is that quality control and quality management have a tremendous impact on the development of process approaches in organizations. Quality control and quality management, in modern business conditions, are of great importance for the realization of all business activities within the organization. The development and efficient application of the process approach are one of the most important prerequisites for long-term profitability of the organization's operations and their market success.

\section{QUALITY CONTROL}

Techniques and methods of quality control of products and services have been widely applied in all segments of human society and have been used for more than one century. Quality has always been seen as an integral part of almost all products and services. However, understanding its importance and introducing formal methods of quality control and its improvement has gone through a large number of phases. The rapid development of interest for quality, which began in the first half of last century, continued throughout this century. Development of quality control, as well as other segments of quality management for the most part is response to the significant changes and many challenges arising in the midst of rapid development of information and telecommunication technologies.

The application of the contemporary concept of quality control began in Japan after the Second World War. The earliest attempts at applying quality control, which are considered and for the first formal activities in the field of statistical quality control, were realized during 1924, by Walter Shewhart, in Bell Telephone Laboratories. [12] Despite these early efforts and attempts of other companies from the United States to implement quality control in its business, still did not exist all the necessary conditions for the implementation of this concept. After the Second World War, Japanese companies put great emphasis on the quality of their products and their control, which led to the rapid development of this concept. It is believed that high quality of Japanese products represented their core competitive advantage that enabled them rapid market success in the countries of Western Europe and the United States.

Quality, in modern business conditions, is a global phenomenon, pervading all segments of business and all parts of the world. In addition to the business environment, quality management and control are an indispensable part of all other segments of the functioning of the society, such as healthcare, education, state administration and so on. Under the conditions of globalization, quality control and its efficient management represent one of the key elements on the basis of which organizations can build their own competitiveness on the market.

\subsection{Literature Review}

Factors influencing the implementation of the quality management system has been analyzed in the largest part of the scientific and research papers concerned with the influence of quality control and quality management on the development of a process approach. Literature analysis may lead to the conclusion that the authors identified different ways in which quality control and quality management influence the development of a process approach. All these methods need to be carefully analysed in order to identify those who have the most significant impact on the development of process approaches.

Bayarcelik and associates have defined key factors that affect the development of innovation and implementation of quality control within the different categories of processes. [1] Kumar and associates define quality management and all activities that are covered as a journey, not as a destination or goal. [9] They further point out that it is a modern systematic approach that is geared towards satisfying the competitive and technological challenges that can be applied to organizations in all fields, all sizes and from all parts of the world. Quality control

IRTIIE Vol. 6, No. 2, 2018 ISSN 1314-8788 (print), ISSN 1314-8796 (online), doi: 10.15547/artte.2018.02.015 
and quality management aim to provide more efficient process implementation and better use of the resources available to the organization. [4]

Kureshi and associates point to the fact that the concepts of quality management and business improvement are often used as synonyms within management research, where there is also a significant level of correlation between them. [10] Bellis-Jones and Hand point to the fact that quality control and quality management can lead to significant improvements in the way the processes are realized. [2] Lee and associates emphasize in their work that quality control and quality management represent a management strategy that aims to improve the quality of organization's operations and to raise the efficiency of the processes within them. In addition, quality control and quality management aim to raise the level of organization's competitiveness and add value to the offerings they place on their customers. [11] Holjevac points out that quality control and quality management are a system that aims to improve the flexibility of process implementation and the achievement of better organization performance. [8]

The aim of this paper is to provide insight into ways in which quality control and quality management can influence the development of a process approach within organizations. In addition to the works of these authors, numerous other sources dealing with this topic has been used in this paper.

\subsection{Historical development of quality control}

Frederick Taylor introduced the first principles of scientific management at the end of the 19th century, where his work was the result of the development of massive industrial production. [7] Taylor's fundamental contribution to Quality Control, which will become a concept much later, was reflected in the division of jobs to the tasks aimed at facilitating the production of the products. The greatest contribution in his work was reflected in great productivity gains, while quality control was not paid more attention. However, thanks to the standardization of production, Taylor's work had positive effects on the quality of the products. During the first half of the 20th century, Taylor's concept was subsequently extended to studies of movement and creation of work tasks, which primarily concerned the increase of labor productivity, with the quality of the products obtained in most cases not paid much attention.

Statistical methods and their application in quality control have a long history, which extends for almost one century. Sevhart developed the concept of statistical control charts in 1924. Significant contributions to the development of quality control in the late twenties of the last century were given by Dodge and Romig who developed within Bell Laboratories a model of statistical sampling which represented an alternative to final control of all products that have been used up to that time. [12] In the mid-thirties of the last century statistical quality control methods were used in Bell, but their value and benefits that they brought were not significantly recognized by other companies and professional public.

During the Second World War there was a significant increase in the use of the concept of statistical quality control within production activities. Short production deadlines imposed by war conditions required the use of statistical quality control techniques to improve the quality of products, above all those intended for warfare.

Immediately upon the end of the Second World War, in 1946, an American Quality Control Association was established. The main goal of this organization was to promote the use of quality improvement techniques that can be applied to all types of products and services. This association held a large number of training conferences and programs, published numerous publications, which significantly contributed to raising the awareness level regarding the importance of quality control. During the fifties and sixties of the last century, the concept of reliability management came up, with several very important quality control

IRTIIE Vol. 6, No. 2, 2018 ISSN 1314-8788 (print), ISSN 1314-8796 (online), doi: 10.15547/artte.2018.02.015 


\section{ARTTIE $Y$}

Ipplied Resseirlohes in Technics, Technologies and Bductation

Journal of the Faculty of Technics and Technologies, Trakia University https://sites.google.com/a/trakia-uni.bg/artte/

books written, which resulted in the development of the understanding that quality control is one of the most important management segments. [12]

During the fifties of the twentieth century, first experiments aimed at providing process and product improvement were created, with initial application within the framework of chemical industry. From the sixties of the 20th century, Japan has devoted considerable attention to the process approach and its development, using the purposefully crafted experiments with the help of which they developed new and improved existing processes, evaluated the design of new products, increased their reliability and efficiency, while improving in the same time a large number of other product design elements. [7] This discovery has led to a significant increase in interest in using experiments, process approaches, and quality control in company operations.

After the 1980s, a significant increase in the application of quality control, primarily statistical methods, occurred in companies from the United States and Western Europe. This growth was partly due to bad business results and large losses experienced by numerous US and European companies in the previous period. Certain industry branches, such as the automotive industry in the United States, were on the verge of failure because of the inability to resist competitors from Japan. The use of process approaches and quality control was one of the most important factors contributing to the recovery of the US economy during the 1980s. As a result of the efforts that have been made towards the implementation of the changes that have been directed towards improving quality during this period, different methods and techniques of management organizations have arisen.

\section{QUALITY MANAGEMENT}

Management is an extremely complex term that has a large number of distinct meanings, depending on the context in which it is applied. Quality management is one of management's segments and is oriented towards providing preconditions for achieving the organization's overall goals related to quality, allocation of resources available to it, processes that are taking place, ensuring its growth and development, and so on. The concept of quality management implies a continuous process based on the respect of pre-defined standards whose purpose is to serve as the basis for creating a quality management system, continuous improvement of standards and constant improvement of product characteristics and quality. [14] Quality standards, like all other standards used in organizations, aim to lead to more successful business operations and more efficient management. Over the last two decades, the trend of integration of individual standardized management systems into a single management system is increasingly present. The main goal that is to be achieved through the integration of obsolete management systems is to create the prerequisites for the continuous realization of all goals of the organization.

The goal of quality management is to provide long-term maintenance and quality improvement programs for the product or service of the organization and its processes. Quality management includes the following activities:

- Identification of key quality determinants, based on the requirements of target market segments,

- Providing customer satisfaction with products and services the organization offers,

- Achieving the desired levels of quality of tangible and intangible elements of products and services,

- Developing a quality culture in all business segments of the organization and involving it in all the processes that take place in the organization,

- Conducting continuous activities aimed at increasing the quality of products and services of the organization, and 


\section{ARTTIE $Y$}

Ipplied Researirches in Technics, Technologies and Eductition

Journal of the Faculty of Technics and Technologies, Trakia University https://sites.google.com/a/trakia-uni.bg/artte/

- Introduction of modern information and telecommunication technologies in order to raise the quality level. [7]

Quality management implies decision-making, which will help to create quality products that will meet or exceed customers' expectations. Efficient quality management increases the organization's revenue, reduces the costs of its business, thus increasing the profit it achieves.

\section{PROCESS APPROACH}

One of the key advantages of quality management systems is that they can significantly assist organizations to raise the level of customer satisfaction. When deciding on purchasing a product, customers expect that they will meet their needs and expectations that they have. They meet their needs and expectations through their requirements called product specifications. Organizations applying a system-wide approach to quality management are investing heavily in identifying customer requirements and in analysis of those requirements in order to gather information on the basis of which they create their own processes that aim to create products that are acceptable to customers and which meet their needs and expectations. [3]

Business processes take place within the framework of all organizations, whereby they depend to a large extent on the size of the organization, its organizational structure and the activities it carries on. Within the ISO 9000 series standards, processes are defined as a set of interrelated activities that lead to the conversion of input elements into outputs. [1] The process approach implies all the situations in which the activities and resources associated with them are managed as the process. [1] Organizations applying a business approach view their business through a set of business processes that help them manage their entire business. All the processes that take place in the organization's boundaries must be accurately identified and clearly labelled, and the responsibility for each of them must be defined. Efficient application of process approach requires the creation of an organizational structure that will enable the management of all processes within the organization.

The process of quality management development and its implementation is composed of several steps beginning with defining the needs of customers and their expectations and ending with the implementation and with process of continuous improvement of the quality management system. The results that the organization will achieve in its work and its profitability depend to a large extent on the quality management process and how it is managed. In practice, the most common case is that output elements of a process represent input elements in the next process that takes place within the organization. The concept of process approach implies systematic identification of the processes used in organizing and managing them. [7]

The use of process approach is one of the most important segments of contemporary business management, where process approach principles are specifically accentuated within ISO standards by which management systems are defined. In ISO 9001 standards organizations are encouraged to accept the application of process approach in their business activities. ISO 9001 standard defines the ways in which organizations must implement, apply, maintain, and document quality management systems. In addition, within these standards are defined the activities that organizations must implement in order to improve the efficiency of the functioning of the quality management system. Within each organization, there is an entire network of different processes whose complexity depends on their activities and size. Each process within the organization contains certain input and output elements and requires certain resources to be successfully implemented. Efficient process management in the organization requires each of them to be assigned to the person in charge of managing it and who is responsible for the occurrence of certain problems.

IRTIIE Vol. 6, No. 2, 2018 ISSN 1314-8788 (print), ISSN 1314-8796 (online), doi: 10.15547/artte.2018.02.015 
Viewing processes as a set of events that take place in a predefined order can help the organization's management significantly to identify the input elements in the process. After identifying all the input elements, one can go through the definition of the resources that are needed and all the activities that need to be done in order to ensure the achievement of the desired results after the realization of the process. It is essential that all processes that take place in the organization are documented in a way that allows them to be unobstructed and efficient. The task of the organization's management is to identify all the processes that need to be implemented in order to meet the demands of the customers and all other stakeholders, and then to ensure the smooth functioning of the process approach in the business. In addition, management needs to provide preconditions for the organization to define processes that are mutually acceptable. [9]

Quality control and quality management aim is to ensure defining, implementing and maintaining all design and development processes that are necessary to meet the needs, demands and expectations of customers as well as all other stakeholders within the organization. When developing a process approach, a special emphasis must be placed on the quality management of the procurement-related processes of operations, primarily to ensure that the raw materials purchased and products fully meet all the requirements of the organization's processes. Modern information and telecommunication technologies have proven to be very useful in managing procurement quality in the process approach, primarily because of the fact that they allow very fast, inexpensive and efficient communication with the organization and its suppliers.

Quality management, when developing a process approach, its implementation, and its usages, should not be confined solely to monitoring the realization process, which must cover within its framework all the activities that take place within the organization. There are a large number of additional quality management activities that a company's management can carry out, such as waste reduction, employee training, increased level of supplier and customer competence, raising the quality of infrastructure, improving communication processes, managing information and keeping them, increasing process efficiency and their better use and so on. [7]

\section{THE QUALITY CONTROL AND QUALITY MANAGEMENT IMPACT ON PROCESS APPROACH DEVELOPMENT}

One of the key factors influencing product quality is the quality of the processes within the organization and the quality of organization's functioning as a system. The emergence of each product is the result of a number of interconnected processes taking place during its production. [6]

In situations where all processes within the organization take place unmistakably, ie when there are no omissions, failures or weaknesses that could adversely affect its business, the quality of products it produces and sells on the market is at a satisfactory level. In order to be able to offer customers high-quality products and services, organizations must ensure that all processes within the framework are carried out without delays, conflicts or failures.[8] Operational quality of the organization's operations is ensured through the pursuit of continuous activities in the direction of improving the processes and activities within it, with particular emphasis being placed on preventing the occurrence of disadvantages, irrational operations and mismatches within the whole product production process.

In managing the processes quality within the organization, in addition to the quality control of each of the processes being monitored, the ongoing control and interdependencies that exist between the individual processes in the chain must be carried out. In the event that only one of the processes in chains has a low level of quality or that there are problems within it, all other chain-related processes will suffer the consequences or be exposed to some of the 


\section{ARTTIE $Y$}

Ipplied Resseirlohes in Technics, Technologies and Bductation

Journal of the Faculty of Technics and Technologies, Trakia University https://sites.google.com/a/trakia-uni.bg/artte/

problems or their quality will be unsatisfactory level.

The processes that are necessary for the successful functioning of the quality management system are not just processes that are directly related to product making or provision of services, but also the activities of managing, measuring and controlling different processes that are not directly related to the creation of products or services, resource management, communication, marketing, finance management etc. Individual processes that take place within organizations are very rarely independent and isolated. Almost as a rule, they exit from one process represent the input elements of the next process.

The degree of interaction that takes place between individual processes within an organization can be significantly different. In certain cases, there may be very complex links between processes, whereby the interaction between them occurs in some cases may also be the consequence of independent processes that are interconnected. Processes inputs and outputs are often associated with internal or external buyers, where they can play a very important role in defining the input requirements of individual processes within the organization. The feedback the organization receives from its customers indicates their satisfaction or dissatisfaction with the products or services, and they represent very important input elements on the basis of which activities are being carried out in the area of improving process quality management.

\subsection{Implementation of process approaches related to quality management requests}

Quality standard ISO 9001:2008 defines the implementation of a process approach that reads: "In situations when implemented within the framework of the quality management system, the process approach emphasizes the importance of:

- Understanding and fulfillment of the requirements,

- The need for processes to be viewed as a function of added value which they bring to the organization,

- Information gathering on the results of the processes and their effectiveness, and

- Continuous improvement of the process based on results obtained by objective measurements." [1]

Observed from the context of the ISO 9001:2008 standard, the process approach within its framework includes all the activities needed to create a product, as well as all the additional processes related to activities of implementing a quality management system, such as the process of internal quality control, data analysis, resource analysis, reporting on quality management etc. [13] All these processes can be managed with the help of standard ISO $9001: 2008$, with the help of the requirements that are given in its segments relating to:

- Quality management system,

- Management responsibilities,

- Resource management,

- Production, and

- Measuring, analyzing and improving. [1]

\subsection{Identification and implementation of the necessary processes}

During process approach development within the organization it is a must to identify all the processes necessary for the realization of its production activities. When identifying business processes, answers to the following questions must be provided:

- Which processes are necessary for the efficient functioning of the quality management system?

- Who is responsible for managing these processes and their realization?

IRTIIE Vol. 6, No. 2, 2018 ISSN 1314-8788 (print), ISSN 1314-8796 (online), doi: 10.15547/artte.2018.02.015 


\section{AR'T'TE

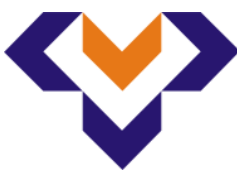 \\ Ipplied Resseirlohes in Technics, Technologies and Bductation \\ Journal of the Faculty of Technics and Technologies, Trakia University https://sites.google.com/a/trakia-uni.bg/artte/}

- Who are internal or external customers of each of the processes that take place within the organization?

- What requirements do customers give to organization?

- Which inputs are used in each of these processes and what are their outputs?

- Is any of these processes external? [14]

After business processes identification, next step is definition of sequence of their occurrence and the mutual relationships between them, by gathering answers to the following questions:

- How does the flow of processes take place within the organization?

- How are the processes listed mutually connected?

- How can this process flow be described and with the help of which tools?

- What documentation is needed to effectively monitor and manage the processes?

The next step in identifying and implementing the processes is the definition of criteria and methods that will help ensure the efficient realization of all processes within the organization and their control. Criteria and methods can be defined by gathering answers to the following questions:

- What are the expected, intentional or accidental results of the processes?

- Based on which criteria will be monitored, measured and analyzed the results obtained from the processes?

- How can the results obtained be included in the activities of planning the quality management system and the processes that take place within the organization?

- By which methods can the best possible results be obtained?

- What are the economic results achieved during the realization of the processes? [13]

After defining the criterion and method, it is necessary to ensure that all informations and resources that are necessary for the realization and monitoring of the processes are available in a timely manner and in the required quantities. During this phase, answers to the following questions are gathered:

- What resources are needed for the realization of each process?

- What channels of communication are used?

- How can feedback be provided regarding the functioning of the process?

- How can I provide the internal and external information necessary for monitoring the process?

- What data have to be collected?

- What information about processes must be kept?

The last phase in implementation and identification of the necessary processes consists of the practical implementation of all those activities required for the realization of the planned results and for the continuous implementation of activities in the direction of improvement of the processes. During this phase, answers to the following questions are gathered:

- How can processes that take place within the organization can be improved?

- Which corrective and / or preventive actions have to be implemented?

- How will the necessary corrective and / or preventive actions be implemented in the organization's business?

- Did corrective and / or preventive actions prove to be effective?

\section{CONCLUSIONS}

In modern business environment, quality control and quality management are of great importance in realizing all business processes that take place within organizations. Process approach as one of the ways of increasing efficiency in the work of organizations gets more and more important, with one of its greatest contributions highlighting the fact that it enables efficient quality assimilation in all processes that take place within organizations. The process

IRTIIE Vol. 6, No. 2, 2018 ISSN 1314-8788 (print), ISSN 1314-8796 (online), doi: 10.15547/artte.2018.02.015 


\section{ARTTIE $Y$}

Ipplied Resseirlohes in Technics, Technologies and Bductation

Journal of the Faculty of Technics and Technologies, Trakia University https://sites.google.com/a/trakia-uni.bg/artte/

approach application enables quality and support processes in organizations to be monitored, enabling a significant increase in the quality of their work, reducing costs and increasing efficiency. Significant influence that quality management has on process approaches in organizations is also reflected in a much simpler and clearer view of the relationship between the individual processes and their mutual interactions.

The significance of the quality control and quality management system, as we have seen from the information presented in the paper, is extremely large. Quality control and quality management are very important segments of all processes that take place in organizations, whether it is processes that are directly related to the creation of products and services, or processes that have an ancillary role. Based on the information presented in the paper, it is concluded that the initial hypothesis of the work has been fully validated, that quality control and quality management have a great influence on the activities of process development in organizations.

\section{REFERENCES}

[1] Bayarcelik E., Tasel F. \& Apak S. (2014). A Research on Determining Innovation Factor for SMEs. Procedia-Social and behavioral Science, Vol. 24, No. 150, 2014, pp. 202-211.

[2] Bellis-Jones R. \& Hand M. (1989). Are total quality management programmes a fact or a management fad?. Management Accounting, Vol. 67, No. 5, 1989, pp. 36-37.

[3] Bisgaard S., Hunter W. G.\& Pallesen, L. (1984). Economic Selection of Quality of Manufactured Product. Technometrics, Vol. 26, No. 1, 1984, pp. 9-18.

[4] Collins R. (1996). Total Quality Management, Effective Management. C.C.H. International, Oakland, 1996.

[5] Drejer A. (2006). Strategic innovation: a new perspective on strategic management. Handbook of Business Strategy, Vol. 7, No. 1, 2006, pp. 143-147.

[6] Galvagno M. \& Dalli D. (2014). Theory of value co-creation: a systematic literature review, Vol. 24. No.6, 2014, pp. 643-683.

[7] Goetsch D. \& Davis S. (2015). Quality Management for Organizational Excellence: Introduction to Total Quality, 8th ed.Pearson, New York, 2015.

[8] Holjevac I. A. (2008). Business ethics in tourism-as a dimension of TQM. Total Quality Management, Vol. 19, No. 10, 2008, pp. 1029-1041.

[9] Kumar V., Choisne F., de Grosfoir D. \& Kumar, U. (2009). Impact of TQM on company's performance. Int. J. of Quality and Reliability Management, Vol. 26, No. 1, 2009, pp. 2337.

[10] Kureshi N., Qureshi F. \& Sajid, A. (2010). Current health of quality management practices in service sector SME - a case study of Pakistan. The TQM Journal, Vol. 22, No. 3, 2010, pp. 317-329.

[11] Lee V-H., Ooi K-B., Tan B-I. \& Chong A.Y-L. (2010). A structural analysis of the relationships between TQM practices and product innovation. Asian Journal of Technology Innovation, Vol. 18, No. 1, 2010, pp. 73-96.

[12] Montgomery D. (2009). Introduction to Statistical Quality Control, 6th ed. John Wiley and Sons, Hoboken, 2009.

[13] Muruganantham G., Vinodh S., Arun C. S. \& Ramesh, K. (2018). Application of interpretive structural modelling for analysing barriers to total quality management practices implementation in the automotive sector. Total Quality Management \& Business Excellence, Vol. 29, No. 5, 2018, pp. 524-545.

[14] Summers D. (2008). Quality Management, 2nd ed. Pearson, New York, 2008. 